\title{
Marcel Kamba-Kibatshi*
}

\section{THE CONTRIBUTION OF THE WORLD BANK ON THE DEVELOPMENT OF THE DEMOCRATIC REPUBLIC OF CONGO AND THE PERSPECTIVES OFFERED FOR THE FUTURE}

\begin{abstract}
A b s tra c t : Currently, thanks to the World Bank, the DRC is experiencing rapid and disorderly urbanization: the 12 largest cities are estimated to have grown by $4.7 \%$ per year. The country's urbanization rate rose from 9.9 per cent in 1956 to 42 per cent in 2015. The country is developing rapidly. This increase is explained in particular in recent years by insecurity and lack of economic opportunities in rural areas. Cities have developed in an uncontrolled way because of lack of urban planning, adequate standards and practices for land management. Growth alone will not bring an end to extreme poverty by 2030 , the report explains, because as the economy develops, the intrinsic effects of growth tend to affect a poor. At this stage, most people still living in the most extreme destitution are in extremely delicate situations to rectify. Additional funding will improve access to essential infrastructure and services (roads and sewer systems, markets, schools, health centers) that will be addressed by the project and will address in part the investment gaps that are particularly acute in provincial capitals . It will also strengthen the programs implemented according to the performance-based approach adopted by the project for access to investment funds, by proposing urban management tools developed in other cities this project. At the request of the Congolese authorities, the activities are based on the recommendations set out in the Urban Review and the Review of the Land Sector in the DRC.
\end{abstract}

K e y w o r d s: World Bank, Financial institution, reconstruction, develop

JEL Codes : C01, D24, E51, G21

\footnotetext{
* The address for correspondence: dr Marcel Kamba-Kibatshi, Ojca Maksymiliana Kolbe Street 15, apartment no.2, 64-920 Piła; e-mail: marcel_kamba@interia.pl lubm.kamba@vp.pl; phone $+48 / 694880827$ or +48500655105
} 


\section{INTRODUCTION}

\section{Problematic}

The development of the Democratic Republic of Congo and the improvement of Congolese living conditions are the most troubling and paradoxically the most complex concepts to analyze especially taking into account the different programs that have been carried out by the government of that country. Realizing that this task of reconstruction, being a difficult and very costly mission, requires enormous financial resources that the state budget alone will not honestly be able to bear. In our opinion, even if the mobilization of internal resources could be maximized, the use of both public and private capital (national and international) is absolutely essential. It is in this spirit that cooperation with all major partners worldwide should be considered. It should be noted that the "Breton Woods Institutions" suspended their financial aid for the Democratic Republic of Congo in 1990, due to the deterioration of the economic and political situation in the country. However, the Democratic Republic of Congo maintained dialogue with the authorities of these Breton Woods Financial Institutions throughout the 1990s, which made it possible to undertake rapid engagement in 2001 and especially in 2010. However, our concern in this work is to estimate the impact of the World Bank's interventions in the reconstruction of the country since its reengagement until 2008. It will be mainly to seek the influence of the contribution of this institution financial support to support economic reforms, and above all to finance reconstruction work, provide sectoral policy advice in this area and play an important (major) role in mobilizing and coordinating donor efforts of funds for sustainable development. But we have been concerned about: - Is the World Bank capable of developing a post-conflict country with immense and multifaceted challenges? What is the impact of this contribution on sustainable development in the Democratic Republic of Congo?

\section{Hypothesis}

We can say that the result of partnership between the Democratic Republic of Congo and the World Bank is barely perceptible. Of course, this perception at a distance is perfectly understandable for a country as large as it is in Europe, apart from Russia, this may explain why proper coordination of the actions of the World Bank is necessary.

\section{Work methods and techniques}

Two methods of approach will be used mainly in the realization of this work. They will be supplemented by a few accepted techniques in the social sciences. These include historical and analytical methods. Historical methods consist in collecting, ordering, and hierarchizing a plurality of facts by establishing a link between the fact studied and the situations that are connected with it, anterior and posterior. The analytical method, on the other hand, allows us to compose and 
examine the components of the problem through various encrypted elements in possession.

\section{Interest and choice of the subject}

At a time when the eyes of all Congolese are turning to the achievements of five projects of the republic for the development, this subject presents a great interest. Secondly, for the Congolese state, this work allows it to get an idea of its share of responsibility and the place that belongs to the financial institutions in general and the World Bank in particular in order to adopt a good policy to guarantee the winning partnership - winner. This work is an opportunity to put into practice all the theoretical economic knowledge acquired.

\section{Delimitation of subject}

Our subject is therefore limited in time and space, our subject will be limited to the international financial institution called the World Bank, our analyzes and investigations will concern the contribution of this one on the sustainable development of the Democratic Republic Congo and its prospects. In time our study will take into account the period from 2001-2008.

\section{Division of the work}

The work is divided into two parts. The first gives an understanding of the world bank, its functioning, its mission, its mode of action and finally the second shows the impact of the World Bank and its strategy for the sustainable development of the Democratic Republic of Congo.

\section{Part I. The presentation of the World Bank}

\subsection{Mission of the World Bank}

The World Bank's priority is to help the poorest populations and countries. The estimated world population of over 2.8 billion is more than half of all developing countries that have less than $\$ 1$ a day and 1.2 billion earn less than $\$ 1$ a day. This finding shows the level of poverty in the context of global population growth, which the World Bank estimates will translate into an increase of about 3 billion people over the next 50 years and is a very big issue. That is why the World Bank has set itself the task of fighting poverty in the world.

This means that :

1. It encourages growth to create job opportunities in the world, etc.

2. It helps the poor to take advantage of these opportunities.

Its mission is also to support all efforts in the context of the investments of the governments of member countries to build: - schools, - health establishments, - ensure the supply of drinking water and electricity, - fight against diseases and protecting the environment[Masamba Makela, 2010, pp. 234-236]. We can say that the World Bank is one of the main sources of development in the world.

\subsection{How the World Bank Works}

The World Bank operates as a cooperative whose member countries are at the same time shareholders. The number of shares held by each member country 
depends on the size of its economy. The Member States and shareholders of the World Bank are:

1. the United States is the largest shareholder with $16.41 \%$;

2. Japan with $7.87 \%$;

3. Germany with $4.49 \%$;

4. the United Kingdom with $4.31 \% 1$

5. France with $4.31 \%$.

The remaining $62.61 \%$ of the shares are distributed among the other member countries.

\subsection{Area of intervention}

The experience of about 64 years has shown and convinced the World Bank that in terms of development, it is up to the country to develop solutions tailored to their own situations, because there are no ready-made solutions that can universal application to all (each) State. But very often, the World Bank proposes a mix of funding and knowledge to promote socio-economic development and help the poor achieve the Millennium Development Goals that the international community has endorsed[Bisengimana, 1998, p. 92].

The World Bank works in partnership with more than 100 developing countries and is involved in several distinct areas. The projects they support allow these countries to invest in health and education, fight corruption, stimulate agricultural production, build roads and ports, and protect the environment. Other bank-funded projects help build war-torn countries or regions, provide essential services such as drinking water supplies and promote job-creating investments[Mpindi Mbesa, 2009, pp. 84-85].

\subsection{Ultimate decision-making power}

The shareholders of the World Bank, ie governments or member countries, are represented by a Board of Governors consisting of the Ministers of Finance or the Development Ministers of each member country[Bibombe Mwamba, 2006, pp.46-47]. The governors have the real decision-making power and meet once a year at the annual meeting. However, when the governors meet, they act in such a way that they assign all the specific responsibilities (tasks) to their directors who are in place on the spot within the bank. Thus, it should be noted that each Member State of the said financial institution is represented by a Director. The five Member States or shareholders holding the largest number of shares, ie France, Germany, the United Kingdom, Japan and the United States each appoint one director and the other member countries are represented together by 19 Directors. And it should be clear that the World Bank has a total of twenty-four (24) directors.

Thus, these 24 Directors, who constitute the Board of Directors of the World Bank, usually meet twice a week to ensure and coordinate the conduct of the Bank's operations. In particular, they decide to follow up on the proposals for 
loans and also loans and guarantees[Ekwa Bis Isal, 2008, pp. 18-19]. Their role is also to: - set new policies, - review the administrative budget, and assistance strategies to countries, as well as decisions on borrowing and financing. The President of the World Bank, according to tradition, is a national of the country with the largest number of votes and is the United States. Usually he is elected for a renewable five-year term and chairs all council meetings.

\section{Part II. The World Bank's actions from the perspective and strategies of harmonious and sustainable development}

\subsection{The achievements of the World Bank for Development ${ }^{1}$}

The World Bank ceased operations in the Democratic Republic of Congo (DRC) in 1990 before returning to it in 2001. This return was gradual, with a first phase from 2001 to mid-2002 that resumed contact with the government and to test the seriousness of the government then a second phase from mid2002 with a formal re-engagement after the Democratic Republic of Congo has cleared some arrears of external debt[Mpindi Mbesa, 2009, pp. 84-85]. The results of the 2006 elections were important because the World Bank was waiting for the government to be legitimate and the security situation to improve. At the economic level, things seem to be moving in the right direction, but it is estimated that with an annual growth of $5.6 \%$, the Democratic Republic of Congo will have to reach 2060 per capita income by 1960. Given the size of the economic recovery is closely linked to the structure of transport.

Hence, the importance and priority given to this sector. Since this formal reengagement, including the first phase of testing the seriousness of the government, the World Bank's portfolio includes from 2001 to mid-2002 a project whose aim was to show the population that it was ready to support the Democratic Republic of the Congo[Lukeni Lunimi, 2009, p.113-114]. From mid-2002 to 2008, the portfolio includes 12 projects that represent commitments of $\$ 2.22$ billion, of which $\$ 1.21$ billion has yet to be disbursed. It should be noted that currently the intervention of the World Bank in the Democratic Republic of Congo is done through 3 parts:

1. Projects;

2. Technical Support;

3. Mobilization of Donors[Annual report of the World Bank, 2010, p.118]. These projects financed by the World Bank cover (3) three sectors:

1. Development of the private sector, including improving the business climate, supporting business competitiveness and reforming the broader public sector.

2. Human development, including health, education and the fight against HIV / AIDS

\footnotetext{
${ }^{1}$ World Bank Portfolio 2008.
} 
3. Sustainable development, including the urgent rehabilitation of roads, infrastructure, urban development, and the demobilization and reintegration of ex-combatants.

\subsection{The actions of the World Bank}

The Millennium Development Goals (MDGs) and their likely expectations in the Democratic Republic of Congo. The whole world is mobilizing through the United Nations to achieve the 8 global objectives below to fight poverty and hunger, illiteracy, injustice to women, mortality of pregnant women and children, HIV / AIDS, environmental destruction and economic inequalities between regions[Annual report of the World Bank, 2013, pp. 195-196].

\subsubsection{Goal 1: Eradicate extreme poverty and hunger.}

The challenge is to halve, by 2015, the proportion of people whose income is less than $\$ 1$ a day and the proportion suffering from hunger; in the DRC, nearly $80 \%$ of households spend less than one dollar per day, per person and $86 \%$ of households consume less than 3 meals a day. The calorific intake is estimated at 1800 calories per day per person while the minimum standard is 2300 calories.

\subsubsection{Goal 2: Achieve universal primary education.}

The challenge is to enable all children, boys and girls, to complete the full cycle of primary schooling. In the DRC, $31 \%$ of children aged 6 to 14 have never attended school.

\subsubsection{Goal 3: Promote gender equality and empower women.}

The challenge is to eliminate gender disparity in primary and secondary education and at all levels of education. In the Democratic Republic of Congo, the Congolese woman has been the victim of sexual violence and discrimination to date. 2 to $3 \%$ of women occupy positions of high responsibility in the national economy.

\subsubsection{Goal 4: Reduce child mortality.}

In the DRC, one child out of five dies before the age of 5, 126 children out of every 1,000 die without having celebrated their first birthday.

\subsubsection{Goal 5: Improve maternal health.}

The challenge is to reduce maternal mortality by three-quarters, by 2015. In the Democratic Republic of Congo, for every 100,000 live births 1,289 women die as a result of pregnancy or childbirth. This maternal mortality rate is one of the highest in the world[Annual report of the World Bank, 2010, pp.91-92].

\subsubsection{Goal 6: Combats HIV / AIDS, malaria and other diseases.}

The challenge is to halt the spread of HIV/ AIDS by 2015 and to begin reversing the current trend. And to have mastered malaria and other diseases. In the Democratic Republic of Congo, the prevalence of HIV infection is 5\% in the estimated population of 15 to 49 years[Annual report of the World Bank, 2009, pp. 24-28]. 


\subsubsection{Goal 7: Ensure environmental sustainability.}

The challenge is twofold: first, to integrate the principles of sustainable development into national policies and to halve the proportion of people who do not have sustainable enough access to safe drinking water. In the Democratic Republic of Congo, the environment has to cope with rapid population growth and rapid urbanization. This results in consequences such as: deforestation, pollution, erosion, insalubrity, etc.

\subsubsection{Goal 8. Establish a global partnership for the development.}

The challenge is to continue the development of an open multilateral trading and financial system to address the least developed specific problems. In the Democratic Republic of Congo, external debt is estimated at nearly USD 14 billion, the weight of which is a major handicap to the development of the country. In addition to the Democratic Republic of Congo, it enjoys little development assistance from the international community and yet its main export products are highly competitive on the international market[Annual report of the World Bank, 2010, pp.91-92 ].

\section{3. "The" organizational, democratic "advances made by the DRC.}

The elections held in 2006 offered the Democratic Republic of Congo a historic opportunity to build a state capable of functioning. But to lay the foundation for progress, it was necessary to establish responsible democratic government and other institutions of the Republic. The Constitution of the Democratic Republic of Congo of February 18, 2006, has in several of these provisions provided for clauses related to the institutions of the Republic and with the decentralization of which many laws are either already published or in the works[Masamba Makela, 2010, pp. 234-236]. The following laws facilitating decentralization have been adopted:

- The Act on Fundamental Principles Relating to the Free Administration of the Provinces;

- The Organic Law on the Composition, Organization and Functioning of Decentralized Territorial Entities;

- Other laws, such as the one relating to the state portfolio to speed up the reform of state portfolio companies.

It emerges from all these laws that the new configuration of the territorial with autonomy can give the Democratic Republic of Congo the possibility of becoming one of the most important reconstruction projects for the whole of humanity in the course of this millennium[Matenda, 2005, p. 46]. Indeed, for the Congolese constituents, entities enjoying legal personality have multiplied at such a pace that it will become possible to achieve Millennium Development Goal 8 with never equal facilities. In the territorial, for example, the city, commune, sector and chieftaincy are decentralized territorial entities endowed with legal 
personality. The Republic will have a total of more than 1041 decentralized territorial entities[Mpindi Mbesa, 2009, pp. 84-85].

\subsubsection{The need for further decentralization and the organization of urban, municipal and local elections.}

The traditional gravity which maintains the social and economic inequalities between centers and peripherals tries to disadvantage the normal pursuit of decentralization and local electoral processes in the Democratic Republic of Congo. In this country, this is generally expressed by the saying: "big fish eat small fish" big cities eat small towns, and "big authorities eat small authorities". For this reason, the central authorities must be pressured to decentralize and the authorities already in power to continue the elections to the local level. Implementation of five-year local Growth Strategy and Poverty Reduction Strategy Papers (PRSPs)[ Tshika Mbwebwe, 2010, pp.69-71]. Contained in a poverty eradication strategy paper in the entity concerned, the local PRSP will be censored and will constitute the contract for the development of local government for five years.

\subsubsection{Some Results of these Projects}

In a very synthetic way, the balance sheet can be summarized as follows:

- Water: 110,000 m3 of additional drinking water in Kinshasa. Rehabilitation of 133 water points and 248 water sources throughout the republic. Development of a sector strategy and a plan of action for the reform of the water sector in urban areas.

- Transportation: 927 dirt roads (Kisangani) and $135 \mathrm{~km}$ of open roads and rehabilitated.

- Education: (1) Rehabilitation of 454 schools, distribution of 3,825,000 textbooks and 106,000 master books and the acquisition of 9,895,000 textbooks and 275,000 teachers' guides in delivery; 2) payment of USD 8 million to 26,000 primary and secondary schools for one quarter of the 2008 school year for operating costs 3) Sectoral strategy: medium-term expenditure framework preparation, consensus between government and partners on a national strategy for the gradual reduction of school fees at the primary level. Institutional diagnosis of the Ministry of Primary Education Secondary and vocational; diagnosis on the impact of decentralization including a proposal for a roadmap for implementation; consultation between the main educational actors leading to the drafting of the National Education Act, a plan for the professional development and career development of teachers.

- Health: 5.3 million nets impregnated with long-acting insecticides during delivery; 3 million doses of anti-malarial drugs for a population of 20 million; rehabilitation of 223 health centers; strengthening of the transfusion safety system in each province; acquisition of ARV and 
treatment of $5127 \mathrm{PV}$

- Demobilization and Reintegration of Ex-combatants: Approval of $\$ 50$ million in additional International Development Association (IDA) funding; 3 agreements in progress for 7,000 demobilized; 5 projects in preparation for 40,000 demobilized.

- Social action: 105 micro projects and 9 completed merchandising facilities; 353 in operation ( 276 schools, 55 health centers, 44 drinking water points, construction of 24 markets and storage area, $25 \mathrm{~km}$ of rural roads). Preparation of the draft organic law on the management of public finance and the financing of the workshop for its finalization; preparing the Medium-Term Expenditure Framework (MTEF) and beginning the process of developing provincial program budgets; finalization and adoption of interim rules for the management of public finances and human resources at the provincial level; and forest concession review.

- Private sector: application of the Democratic Republic of Congo to membership in Organization for the Harmonization of Business Law in Africa (OHBLA); approval of the laws governing the management of public enterprises. Adoption by the Supreme Court of Justice of 4 reform measures forming part of the "Doing business" reform compact relating to the registration of enterprises in the Democratic Republic of Congo.

\subsubsection{A proposal for an outline of a financing project by the World Bank and / or other donors to carry out an economic boom in the DRC}

One of the best ways to provoke an economic boom in the Democratic Republic of Congo (DRC) is to adequately finance the decentralization process according to the deep aspirations of the Congolese population[Annual report of the World Bank, 2009, pp. 24-28]. This is achieved by systematically achieving the MDGs in each entity, including human, financial and material resources, with an effectively zero tolerance for predators of all calibers. In a rough way we can estimate to a million US dollars the minimum amount to be injected into each entity in order to vitalize it as funding for its local PRSP. If we consider the decentralized territorial entities, a summary and provisional addition gives:

- 26 provinces: 26 cities;

- 145 territories: 145 communes + 97 urban municipalities. - 737 communities (476 sectors and 261 chiefdoms).

That is to say more than 1,041 autonomous entities, thus 1041 DSCRP local to be funded, that is to say, design, development, implementation, monitoring, one-word evaluation necessary for total success briefly 1.000.000x 1041 gives 1041.000.000 USD for a period ranging from 3 years to 5 years. According to the requirements of the decentralized territorial entities (DTE). 
The advantage of the approach is to make the funds available within their use entities for better perception, management, accountability and consequent insurance of local reimbursement. Thus, instead of attending the brain drain, we will witness the urban exodus because people go wherever there is the means.

\section{CONCLUSION}

Our research topic was the contribution of the World Bank on the development of the Democratic Republic of Congo and the prospects for the future. It seemed useful to recall some basic concepts: economic growth, the path of economic development, underdevelopment and a historical overview of the Congo economy. In order to better know what to do with it, and how to go about it, it was important to present the World Bank with its institutions, missions and mode of actions. Projects carried out by the World Bank in the Democratic Republic of Congo are scattered throughout the country. We have grouped them into components and sub-components, which is too global in the 5 pillars of the Growth and Poverty Reduction Strategy Papers (PRSP). In view of these promising results, which are included in Chapter 3, Section 1.3, and which foreshadow a better future for the Democratic Republic of Congo, the authorities are called upon to coordinate well the World Bank's actions. And this is because as it is said aid will never be eternal for the Democratic Republic of Congo. In order for the average Congolese to feel the effects of economic growth in his country through World Bank assistance or assistance, certain priorities must be met internally:

- implementation of urban, municipal and local elections;

- the implementation of decentralization;

- application of local Growth Strategy and Poverty Reduction Documents.

Implementation of the above points will enable the World Bank to reach the target population and finally to offer quality services and governors to govern in participatory management. It is thus up to each individual to profile all the opportunities that are available in order to ensure with responsibility the future of each citizen. We remind our readers that the analytical results of these projects on the development of the Democratic Republic of Congo will be presented in our future research.

\section{BIBLIOGRAPHY}

Bibombe Mwamba, (2006), Les élément des finances publiques, éd. BIOMETRIX, Kinshasa, RDC

Bisengimana R., (1998), La PME moteur de développement, Éd. CADICEC, Kinshasa, $\mathrm{RDC}$ 
Ekwa Bis Isal M., (2008), Vademecum du gestionnaire de la PME, fascicule II, créer et gérer une PME, éd CADICEC, Kinshasa, RDC

GUY Verhagen, (2005), Le rôle du secteur informel dans le développement économique du zaïre, Ed. CADICEC-information $\mathrm{n}^{\circ} 44$, Kinshasa, RDC

Lukeni Lunimi, (2009), Comment créer une PME en RDC », Formalités juridiques essentielles, éd GRICED, Kinshasa, RDC

Masamba Makela J.R., (2010), Le droit économique, la PME moteur de développement, Éd. CADICEC Kinshasa, RDC

Ilunga Bukasa P., (2011), L'apport de la micro-finance et PME dans le développement de la $R D C$, Éd. BIOMETRIX, Kinshasa, RDC

Matenda A., (2005), La gestion des PME, Éd. PUF, Kinshasa, RDC

Mpindi Mbesa, : (2009), Le droit des affaires, notes de cours, Éd. CADICEC, Kinshasa, $\mathrm{RDC}$

Tshika Mbwebwe, (2010), L'apport du financement des PME dans l'économie nationale, Éd. Éd. BIOMETRIX, Kinshasa, RDC

Annual report of the World Bank, 2009,2010, 2012 and 2013, 2015

\title{
WKŁAD BANKU ŚWIATOWEGO W SPRAWIE ROZWOJU DEMOKRA- TYCZNEJ REPUBLIKI KONGA I PERSPEKTYWY OFEROWANEJ NA PRZYSZŁOŚĆ
}

\begin{abstract}
Streszczenie: Obecnie przy pomocy Banku Światowego DRC doświadcza szybkiej i zdeformowanej urbanizacji: szacuje się, że w 12 największych miastach wzrost ten wyniósł 4,7 procent w skali roku. Wskaźnik urbanizacji w kraju wzrósł z 9,9 procent w 1956 r. do 42 procent w 2015 r. Kraj ten rozwija się bardzo szybko. Wzrost ten thumaczy się zwłaszcza w ostatnich latach niepewnością i brakiem możliwości gospodarczych na obszarach wiejskich. Miasta rozwinęły się w sposób niekontrolowany ze względu na brak planowania przestrzennego, odpowiednie standardy i praktyki zarządzania gruntami. Sam wzrost nie doprowadzi do zakończenia skrajnego ubóstwa do 2030 r., ponieważ w miarę rozwoju gospodarki wewnętrzne skutki wzrostu mają tendencję do słabnięcia. Na tym etapie większość ludzi wciąż żyje w najbardziej ekstremalnej nędzy i znajduje się w bardzo trudnej sytuacji. Dodatkowe finansowanie z pewnością poprawi dostęp do infrastruktury i usług (dróg i sieci kanalizacyjnych, rynków, szkół, ośrodków opieki zdrowotnej), co umożliwi częściowe zlikwidowanie tzw. luk w inwestycjach, które są szczególnie dotkliwe w stolicach prowincji. Takie rozwiązania będą możliwe dzięki udziałowi w projekcie skierowanym w celu uzyskania dostępu do funduszy inwestycyjnych poprzez proponowanie odpowiednich narzędzi zarządzania miastami opracowanymi na podstawie projektów innych miast. Na prośbę władz kongijskich działania opierają się na zaleceniach przedstawionych w przeglądzie miejskim i przeglądzie sektora lądowego w DRK.
\end{abstract}

Słowa kluczowe: Bank Światowy, instytucja finansowa, odbudowa, rozwój 
